\begin{tabular}{|cc|c|}
\hline ISSN (Online): 2367-6957 & ISSN (Print): 2367-6361 \\
Izvestiya Journal of Varna University of Economics 3 (2020) & IZ V E S T I Y A \\
Journal of Varna University of Economics \\
http://journal.ue-varna.bg
\end{tabular}

\title{
A CRISIS WITHIN THE CRISIS: THE IMPACT OF COVID-19 AND BREXIT ON SUPPLY CHAINS IN THE PHARMACEUTICAL INDUSTRY
}

\section{Ralina Dobrinova MIRCHEVA ${ }^{1}$}

${ }^{1}$ Department of International Economic Relations, University of Economics, Varna, Bulgaria. E-
mail: ralina_dobreva@ue-varna.bg JEL: F23, F61, L65, M16

\begin{abstract}
The United Kingdom's decision to leave the European Union creates a situation which will be observed by researchers and economists for quite a while. Keeping in mind that the UK and the EU were already facing many difficult challenges, the global pandemic took the world by storm and sparked disputes about the economic stability of countries around the globe. In the beginning of 2020 the unknowns surrounding Covid-19 and the two crises in the EU caused a "black swan" phenomenon (Taleb, 2007).

Some of the questions which concern many European countries are where and how the deliveries of medical supplies (which are crucial during these times) will be arranged. The main goal of this paper is to examine the measures taken by the pharmaceutical industry in the
\end{abstract}

Key words:

Brexit; Covid-19;

Pharmaceutical supply

chain; UK

pharmaceutical

companies; China.
(C) 2020 University of Economics - Varna

Citation: MIRCHEVA, R. D. (2020). A Crisis Within the Crisis: The Impact of Covid-19 and Brexit On Supply Chains in the Pharmaceutical Industry. Izvestiya Journal of Varna University of Economics, 64 (3), p. 352 - 368. DOI: 10.36997/IJUEV2020.64.3.352 


\section{Introduction}

The United Kingdom left the European Union on 31 January 2020 after three years of negotiating exit conditions. Brussels and London have agreed on a transitional period until the end of 2020, during which all European standards apply to the United Kingdom. The parties must agree on procedures that will regulate their future relationship. Meanwhile, in early February 2020, Europe was shaken by the Covid-19 pandemic. In this crisis situation, one of the main issues is related to the provision of medicines and medical equipment. Since a large number of the world's pharmaceutical companies are based in the UK or have a huge presence on the island, the article looks at how pharmaceutical companies organise their supplies in the event of a probable exit from the EU. The study is also oriented to the possibilities of the pharmaceutical business to respond adequately and to reorganise their supply chains under the dynamics provoked by the virus. An attempt will be made to draw a parallel between how the pharmaceutical business in the UK reacts to the clarity of Brexit and how it works at the onset of the pandemic crisis.

The survey includes the period from which the results of the referendum are formalised, to the current moment when the pandemic has not yet subsided. The fact that the epidemic originated from Wuhan, China, is indicative and defining. China dominates the pharmaceutical business world. Following these two statements the paper focuses on the impact of the Chinese pharmaceutical supply industry on the EU and the UK. The negative effects caused by the pandemic will be perceived on the one hand as a problem and on the other as an opportunity to optimise processes and improve planning activities in such crisis situations. The paper aims to clarify Britain's dependence on the supply of medicines and medical supplies from China. We pose the question, what the possible measures that can be taken to restore pharmaceutical supply chains are. The analysis relies on comparative research methodology.

\section{General state of world pharmaceutical trade}

The global pharmaceuticals market was worth $\$ 934.8$ billion in 2017 and will reach $\$ 1170$ billion in 2021, growing at 5.8\%, according to a recent pharma market research report by the Business Research Company (2018). Healthcare as a whole is growing at over $7 \%$ year on year. The factors that affect the pharmaceutical market size include disease prevalence, drug affordability, consumer attitudes, government policies and some supply-side factors. Disease prevalence is related to population size, age, genetic inheritance and behaviour (infectious disease incidence is lower 
where sanitation practices are better; sedentary lifestyles also encourage chronic disease). Affordability is related to income but also to drug prices. Consumer attitudes include willingness to use alternative therapies or distrust of taking drugs. Government (and insurance company) policies affect reimbursement and who the payer is. A major supply-side factor is availability of an appropriate treatment, which may be a matter of quantity, as in an epidemic, or of drug discovery and development.

The pharmaceutical industry accounts for tens of billions of dollars in international trade each year, the bulk of which comes from Europe and the United States. Though many people around the world are concerned about the growing demand for pharmaceuticals, this demand is fuelling the growth of massive pharmaceutical companies. As such, the industry is likely to continue to play a major role in the global economy in the coming years.

Figure 1 shows the world leaders in the pharmaceutical markets for 2018. The market leader is the USA, followed by almost 30\% difference from China. The UK holds almost $2.4 \%$ of the market share.

\section{Market share of top 10 pharmaceutical markets worldwide in 2018}

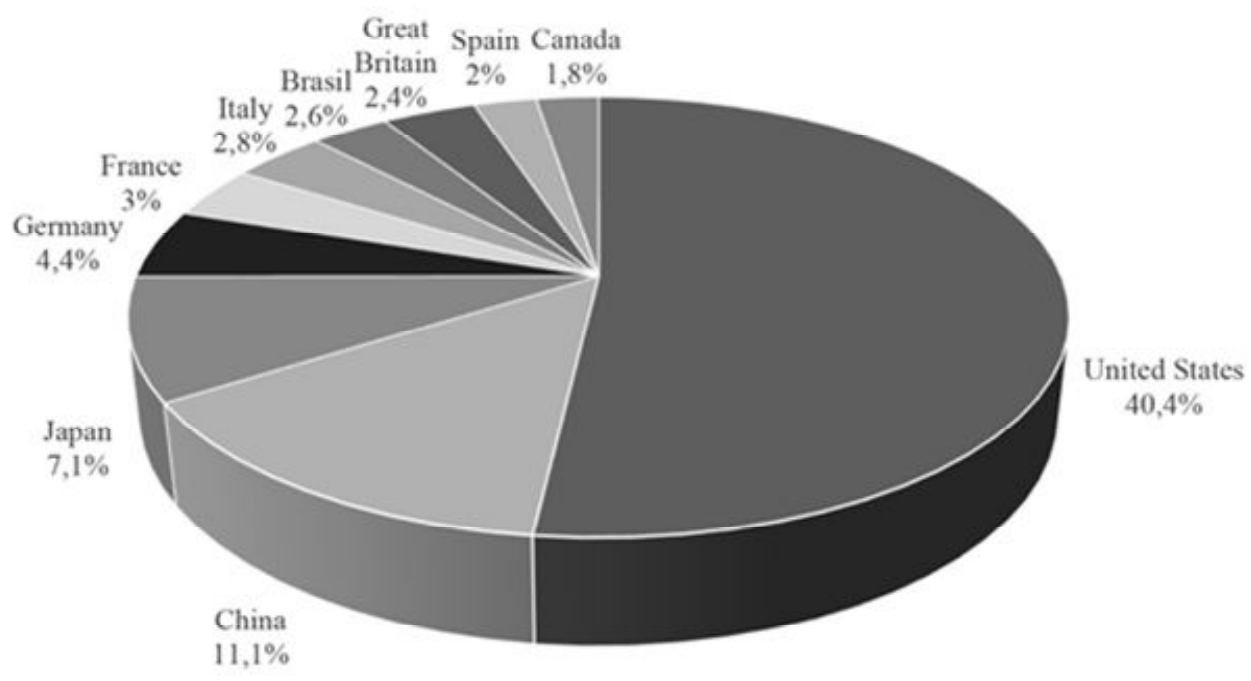

Fig. 1. Market share of top 10 pharmaceutical markets worldwide in 2018. Source: IQVIA. (n.d.) 

and Brexit On Supply Chains in the Pharmaceutical Industry

As the subject of the paper is the supply chain after the announcement of Brexit and after the appearance of Covid-19, we focus on the pharma trade in the UK and China. According to WTO the UK ranks $5^{\text {th }}$ in the EU in exports of medicines and medical devices (Table 1). As Boshnakov (2006) states, the EU negotiation process with third countries depends on the political situation and current trade priorities. The value of exports of medical devices and medicines accumulated by the United Kingdom is $\$ 33,585.5$ million.

Table 1

Leading Exporting and Importing Economies in Pharmaceuticals, 2017

\begin{tabular}{|c|c|c|c|}
\hline \multicolumn{2}{|c|}{ Exports } & \multicolumn{2}{|c|}{ Imports } \\
\hline Country & Million US dollars & Country & Million US dollars \\
\hline Germany & $84,679.7$ & United States & $99,714.8$ \\
\hline Switzerland & $71,706.2$ & Germany & $53,743.9$ \\
\hline United States & $49,693.7$ & Belgium & $36,661.0$ \\
\hline Belgium & $45,685.0$ & United Kingdom & $33,766.3$ \\
\hline Ireland & $40,041.3$ & Switzerland & $29,330.5$ \\
\hline Netherlands & $35,871.7$ & France & $27,792.0$ \\
\hline United Kingdom & $33,585.5$ & China & $26,246.3$ \\
\hline France & $32,231.4$ & Italy & $26,151.0$ \\
\hline Italy & $27,021.5$ & Japan & $23,191.1$ \\
\hline China & $15,066.6$ & Spain & $14,708.3$ \\
\hline
\end{tabular}

Source: WTO (n.d.).

Total exports of protective products, including face masks, hand soap, sanitiser and protective spectacles, were valued at $\$ 135$ billion on average for the period 2017 2019. About $17 \%$ or $\$ 23$ billion came from China, the top exporter, followed by Germany and the US. These three exporters account for more than $40 \%$ of world exports of protective supplies (Fig. 2). 


\section{Share of top 10 exporters of personal protective equipment}

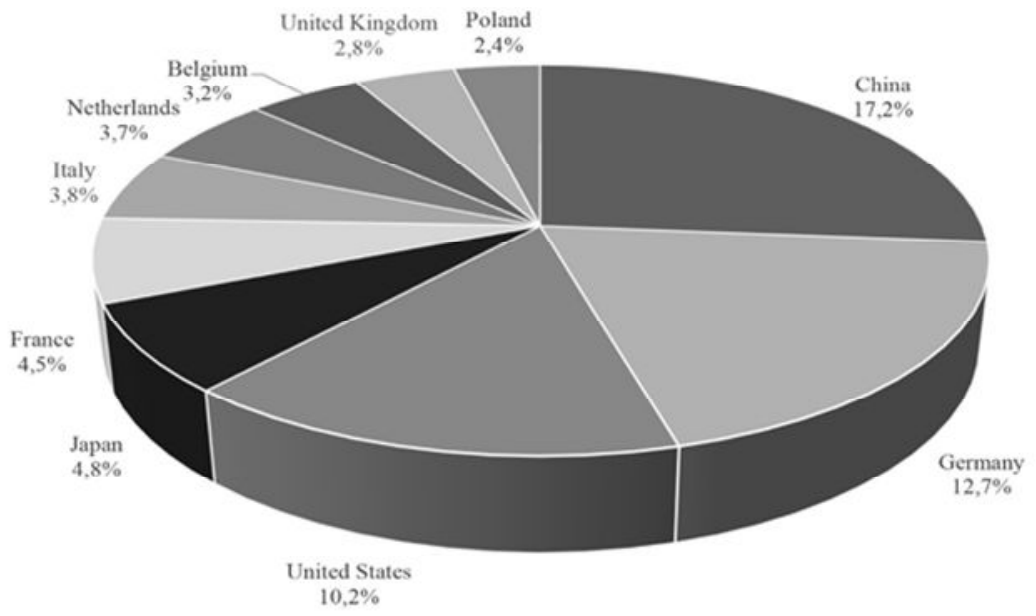

Fig. 2. Trade in medical goods in the context of tackling Covid-19

Source: WTO (2020).

\section{Worldwide trade difficulties as a result of Covid-19 pandemic}

In early April 2020, the World Trade Organization announced that global merchandise trade was set to plummet by between $13 \%$ and $32 \%$ in 2020 as a result of the Covid-19 pandemic. With concerns rising about medicine availability during the global Covid-19 coronavirus pandemic, European Pharmaceutical Review explores how the pharmaceutical supply chain is faring. Among the problems for pharmaceutical supply chains during this pandemic are the restrictions and impact of Covid-19 on two of the largest global producers of active pharmaceutical ingredients (APIs) and generics: China and India. According to Rincon-Aznar (2020) the world is undergoing an unprecedented shock as a result of the Covid-19 pandemic and the widespread lockdowns. As major world economies are being put on hold, millions of jobs and incomes are being lost, which has created an imperative for economic policy actions to counteract the falls in demand and increased market uncertainty. As Covid19 constitutes a vivid example of an unexpected shock with global reach, Brexit will continue, once this crisis is over, to shape the domestic and EU economies, as a new economic and political relationship is established between the UK and the EU. Both these events, in sequence and taken together, undoubtedly imply widespread changes 
to the way in which countries and firms will trade in future decades. It is becoming clear that the economic and social consequences of the current crisis will be profound and long lasting, given the extent to which the economic crisis is transmitted not only through domestic policies but through disruptions to global supply chains.

McGuinness (2020) claims that the UK is approaching negotiations on the basis that it is now fully independent and sovereign and does not want to be tied to the EU. The pandemic demonstrates that, as much as the UK might want to take back full control, the ability to make decisions completely on their own of the rest of the world is not always wise or even possible. And we see there is real value in working together. Severing an existing relationship to go it alone may be more painful than profitable.

\section{China as a major player in the supply of pharmaceuticals and medical devices}

It would not be an inaccurate statement if we say that China is the biggest factory of the world. The pharmaceutical sector also plays a huge role in the Chinese industry. Most of the pharmaceutical companies have established production bases in China. According to $\mathrm{Ti}$ (2020) the vast majority of the active ingredients used in pharmaceutical products consumed in the West are manufactured in China. Despite the turmoil, caused by the pandemic, China has shown an incredible resilience in terms of its production. Many factories returned to work immediately at the end of April. The high levels of inventory which exist in the pharma supply chain (typically 180 days plus) should mean that the disruption is kept to a minimum. According to MannersBell, Ti's CEO, Chinese exporters provide Active Pharmaceutical Ingredients (APIs) and the chemicals which are used to make them - to the manufacturers in other countries for processing ( $\mathrm{Ti}, 2020)$. One of the issues with drug manufacturing is that it can be difficult to speed up, therefore companies need to maximise available capacity to meet backlogs. Large part of the production of medicines takes place in China in order to realise two goals - a cheaper medicine for the manufacturer and respectively for the consumer. In addition, China is a major producer of intermediate ingredients for the medicines. This is explained by the fact that Europe has stricter regulations regarding heavy productions. So for environmental reasons and lower barriers, large British companies, and not only, are adapting production bases in Asia.

In early 2020 the world learned that a novel and deadly coronavirus had appeared in the Chinese city of Wuhan. In February many chemical plants across China were ordered to close for a one-week extension of the New Year holiday, after which quarantines impeded the return to work. By the end of that month, a significant break in the 
pharmaceutical supply chain appeared imminent as the virus and Covid-19, the disease it causes, spread across the Northern hemisphere. As Mullin (2020) has identified, as of April, the chain remains yet largely functional and intact. Chinese suppliers are back in operation, and US and European API producers continue to operate without serious impediment. Manufacturers generally keep emergency stocks of ingredients on hand, and most claim they are not yet threatened by a slowdown in deliveries of raw materials.

In this line of thought it can be said that the pandemic can be a cause for Europe to reorganise its supply process. The danger of the oldest continent being dependent on China's reserves has been recognised. In recent years, more and more western pharmaceutical corporations, such as Pfizer, GSK, Roche, Novo Nordisk, have set up commercial operations and R\&D centres in China. Many world leading pharmaceutical companies have established joint venture manufacturers in China. Some have even set up their own manufacturing facilities. The main reasons for overseas companies going to China have been to save costs by using the extensive science and technology research bases currently in place in the country, the abundant human resources, and less expensive medical and clinical trials. China is a huge market for big pharma. Chinese stability and integrity of the supply chain also make a lot of sense to them. After this, China is maybe the only country to resume normal work and normal manufacturing.

The protection of human health is a priority for the countries concerned, so the supply of medicines is carried out at a local level first. The crisis situation in the face of the pandemic has shown that in the event of economic closures and huge delays in the supply of medicines, countries can rely only on their meat stocks.

\section{Disruptions of the supply chain in the United Kingdom}

The pandemic provoked the global forces, and as a result of the restrictive measures taken by large entities and structures, a global socio-economic crisis was caused. The challenge for societies was to protect the health of the residents. The main question was how medicines and medical supplies would be delivered given the fact that the states were literally closed. Goods movement restrictions, imposed by the majority of EU countries at their borders to control the spread Covid-19, are disrupting supply chains, including crucial medicines and medical equipment supplies. Whereas imposing internal borders had never been in the EU's plans before the Covid-19 outbreak, the UK - which is due to leave the bloc by the end of the year - needs to keep a close eye on supply chain issues to avoid the same problems once customs checks are imposed between the EU and the UK. The Senior Director of Market Research at GlobalData U. Jakimaviciute says: 
"For pharma it would mean continued pressure on the UK's medicines supply chain, as despite the scale of the UK pharmaceutical industry, the UK imports a significant amount of medications from the EU, with Dover and Folkestone being main entry points. To cope with the supply issues, the EU has introduced fast-track lanes - priority channels for the transport of much needed goods, including medicines. For freight transport going through these lanes, border crossings should be accessible 24/7 and, according to the EU guidelines, border processing time should take no more than 15 minutes. While the 'green lanes' are easing up the pressure of supply shortages in Europe, including critical hospital medicines used to treat Covid19 patients, the wait times are still not down to the 15 minute target at the busiest checkpoints. If a similar system is implemented in the UK, the waiting time may be much longer, as carriers are required to undergo only minimal checks in the EU. Currently the UK's pharma sector is part of the integrated EU supply chain that ensures frictionless transfer of pharmaceutical ingredients and finished goods within the bloc. Whereas the UK's politicians praised the idea of implementing a high-tech digital border and electronic identification to ease up custom checks post-Brexit, it may not happen within the current transitional period time frame. Any digital borders require technological uniformity and legislative framework to be established before the digital check can take place." (GlobalData, 2020)

As prof. Vesselina Dimitrova (2014) claims, transport services in one country could be offered by foreign companies. This is due to the opening of national markets to foreign companies. However, the delivery of pharmaceutical products has been affected by Covid-19, especially those medicines that address its symptoms (paracetamol/aspirin) and the underlying health conditions that the virus exploits (diabetes medication, asthma inhalers, heart medication) (Roscoe, 2020). The pharmaceutical supply chain is more global than that of standard grocery staples and is therefore more affected by Covid-19's quick spread around the globe. Many of the active ingredients that go into pharmaceutical products are sourced and manufactured in China and then shipped to India for formulation and packaging. When the virus emerged in China it quickly shut down pharmaceutical manufacturing facilities, directly impacting medicine supply. Pharmaceutical supply chains therefore face two major supply disruptions within a three-month period. Pharmaceutical supply is further restricted due to labour shortages in the wholesale and distribution of generics and other pharma products to UK pharmacies, as well as shortages with pharmacy staff. Finally, panic buying has led to a spike in demand for medicines directly linked to the symptoms of Covid-19 and the upper respiratory system. Long globalised supply chains, with already disrupted supply, will have difficulty in quickly 
responding to huge spikes in demand. The one saving grace of the pharmaceutical industry is that pharma companies tend to hold significant amounts of inventory in the supply chain, often up to six months, meaning that they can fill demand if the panic buying situation stabilises in the next few months. However, if excessive demand in the UK couples with decreased supply from India, there could be significant shortages of key medicines in the near future.

As most of the pharmaceutical ingredients are manufactured in China and packaged in India, the pharma supply chains are disrupted at the first level: Raw Material Suppliers (Fig. 3). The Wuhan pandemic and subsequent border closures in almost all of Europe have caused huge supply delays. This proves once again Europe's dependence on China for raw materials.

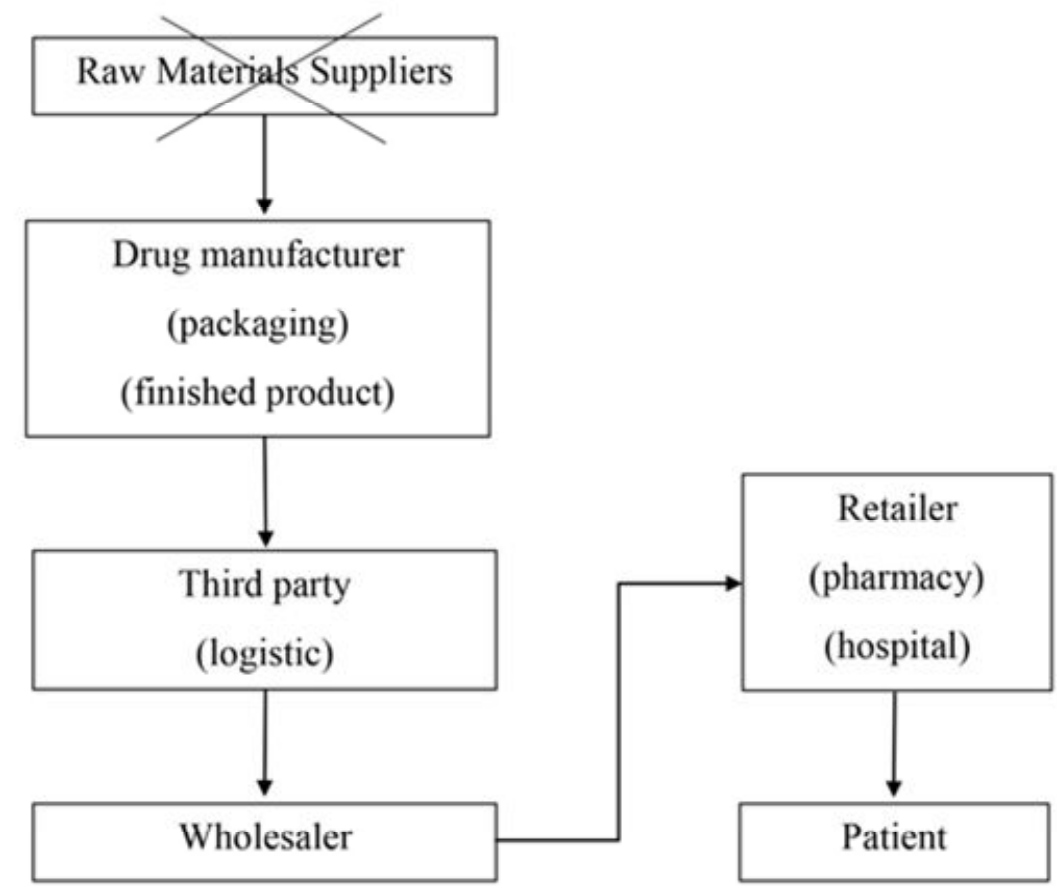

Fig. 3. Disruptions of the supply chain in the UK caused by Covid-19

However, China recovered relatively quickly from the pandemic and regained its normal productivity. The fact that there is cyclicality in crises, however, should not be underestimated. If the restrictive measures due to the coronavirus had lasted longer, then Europe and the UK, respectively, would have met serious supply problems. 


\section{Case studies}

In order to monitor the processes resulting from the announcement of Brexit and the appearance of Covid-19 crisis, it is necessary to pay particular attention to pharmaceutical companies that are taking steps to interact with the rest of the world.

The Association of the British Pharmaceutical Industry is in regular contact, both with its members and the government about any impact that the coronavirus could have on medicine supply in the UK and EU. According to the ABPI (2020) there are robust procedures in place to manage the supply of medicines in the UK, and companies will be taking all possible measures to secure supply for patients - in line with government guidance. Pharmaceutical companies continue to work to understand any impact that closures of global manufacturing facilities (particularly in China and India) may have on supply chains. Companies continue to review this on a daily basis and are working with global colleagues to understand any potential impact. However, this should not be seen as an alternative to information received directly by the relevant competent authorities and government from marketing authorisation holders or suppliers, which should continue to be the primary means of intelligence on continuity of medicine supply. Every day millions of patients rely on medicines supplied by the pharmaceutical industry. Manufacturers know that any medicine shortage is extremely worrying for the people affected by it. Companies work to prevent shortages happening in the first place, but despite the best efforts of all concerned, supply problems can happen for unforeseen reasons. In this report I will focus in particular on pharmaceutical companies with a large presence in the UK on how to deal with retail supply chains.

Pharmaceutical companies in the UK began preparing their supply chains as early as the announcement of Brexit in 2016 due to the ambiguity that arose from this decision through the referendum. At the same time the emergence of Covid-19 has brought the world to a standstill. This health crisis has brought an unprecedented impact on businesses across industries. Firstly, companies have organised their trade for no-deal Brexit and after the beginning of the pandemic, they reorganised their supply chains.

\section{- AstraZeneca}

According to Leonard (2020) the company is making changes to packaging, getting the necessary licenses, duplicating testing in the UK and EU and lobbying the EU to accept UK testing standards for drug makers. They have moved stock from the UK to European distribution centre to be as close as possible to customers on Brexit day and built an additional six weeks of stock for UK supply, in line with the 
government request and four weeks extra stock for EU supply. AstraZeneca is looking at alternative transportation routes.

On the other side, according to AstraZeneca's official site, the company guarantees that medicines supply chain is robust, and the team continues to monitor the situation closely and that they ensure the needs of patients first. They minimise any potential disruption. They are seeing higher than expected demand across some of their medicines. As the UK's leading global biopharmaceutical company and investor in life sciences, the company is working closely with the UK Government and the NHS to support the national response to the Covid-19 pandemic in every way. AstraZeneca has been active in the Chinese market for years. Just last year, it announced it was setting up a one-billion-dollar fund in China to accelerate work in the life sciences. General Manager Michael Lai said that Covid-19 won't interfere with AstraZeneca's plans for a global research and development centre (Tong, 2020). The company also plans to set up regional headquarters in five other cities. Even during the pandemic, China has shown very strong resilience. The company has invested in the past more than one billion dollars overall and an additional 1.5 billion in research and development. From this, they have made China their second-largest market, and they continue to expand their footprint locally.

\section{- GlaxoSmithKline}

GSK (2020) has evaluated the impact of Brexit on their business operations, including their supply chain and quality oversight. The priority for the company is to maintain the continuity of GSK's supply of medicines, vaccines and health products to our patients and consumers in the UK and the EU. Uncertainty remains about the future relationship between the UK and the EU. As a result, they have agreed a riskbased approach to mitigation across the organisation. Implementation of their contingency plan has been underway since January 2018, with an immediate focus on our supply chains. This includes expanding their ability in the EU and the UK to conduct re-testing and certification of medicines; transferring Marketing Authorisations registered in the UK to an EU entity; updating packaging and packaging leaflets; amending manufacturing and importation licences, and securing additional warehousing. The company anticipated that the cost to implement these and other necessary changes could be up to $£ 70$ million over the next two to three years, with subsequent ongoing additional costs of approximately $£ 50$ million per year, including additional customs duties and transaction or administration costs. These charges represent the estimates of the impact of Brexit based on the information currently available. At the same time GSK Consumer Healthcare is prioritising actions in its supply chain to deliver more products that are in high 
demand, due to Covid-19. This includes increasing production for pain relief brands such as Panadol and multi-vitamins and dietary supplements such as Emergen-C and Centrum. The company experiences some delays with distribution and delivery of products to customers as countries around the world introduce different virus containment measures, such as border closures and flight suspensions.

\section{- Pfizer}

Pfizer is a company with a major presence in the UK pharmaceutical industry. Because of Brexit the costs to revise its manufacturing and supply chain is about $\$ 100$ million (Palmer, 2020).

Because of Covid-19, Pfizer has increased the production, shifted demand to the most critical products, and authorised overtime at many sites to meet patient needs. The company also implemented an enhanced demand monitoring and order management process and instituted a heightened logistics control program to ensure the products get from their sites to the customers. They have expanded the use of Digital Operations Center, which is a Pfizer-developed digital solution that enables their supply operations. The expansion provides visual management and action tracking capabilities that allow colleagues at their sites either physically or virtually - to stay connected and work collaboratively while maintaining social distance guidelines (Pfizer, 2020).

\section{- Novartis}

Switzerland-based Novartis warns over huge impact of "no-deal Brexit". Novartis has joined many other rival pharmaceutical companies - including Sanofi, Roche, Pfizer, and AstraZeneca - in starting to draw up plans which will protect Britain's stockpiles of life-saving medication, should a "no-deal" Brexit scenario occur. DeArment (2019) says that Novartis has begun securing additional warehousing in the UK in order to increase the amount of stock medicine they can store. It's presently sufficient to keep ten weeks' worth of stock at any one time, but the new warehousing would enable this buffer to be increased to 14 weeks, allowing the industry to more comfortably absorb any potential delays in re-stocking. It has also been suggested that some manufacturing operations will be moved out of the UK and into Europe to help guarantee supplies in the EU. More than 2,600 drugs presently have some stage of manufacture in the UK.

As Novartis continues to closely monitor the coronavirus situation, their primary concern is the health and safety of their patients globally. They will continue to deliver their medicines to patients around the world and they do not anticipate supply chain disruption at this time. Novartis has also put the following measures in place: they are implementing general international travel restrictions; they have issued guidance on how their associates can protect themselves against coronavirus 
infection; they have enacted mitigation plans where needed to protect the integrity of their trials and help ensure continuity of treatment (Novartis, 2020).

The information on the organisation of the supply chain carried out by the largest pharmaceutical companies in the United Kingdom, can be summarised in Table 2.

Table 2

\section{Organisation of supply chain}

\begin{tabular}{|c|c|c|c|c|}
\hline & AstraZeneca & GSK & Pfizer & Novartis \\
\hline Brexit & $\begin{array}{l}\text { - making } \\
\text { changes to } \\
\text { packaging; } \\
\text { - getting the } \\
\text { necessary } \\
\text { licenses; } \\
\text { - duplicating } \\
\text { testing in the } \\
\text { UK and EU }\end{array}$ & $\begin{array}{l}\text { - re-testing and } \\
\text { certification of } \\
\text { medicines } \\
\text { - transferring } \\
\text { Marketing } \\
\text { Authorisations } \\
\text { registered in the UK to } \\
\text { an EU entity } \\
\text { - updating packaging } \\
\text { and packaging leaflets } \\
\text { - amending } \\
\text { manufacturing and } \\
\text { importation licences } \\
\text { - securing additional } \\
\text { warehousing }\end{array}$ & $\begin{array}{l}\text { - revise its } \\
\text { manufacturing } \\
\text { and supply }\end{array}$ & $\begin{array}{l}\text { - securing } \\
\text { additional } \\
\text { warehousing } \\
\text { - increase the } \\
\text { amount of stock } \\
\text { medicine }\end{array}$ \\
\hline Covid-19 & $\begin{array}{l}\text { - expanding } \\
\text { their activities } \\
\text { in China }\end{array}$ & $\begin{array}{l}\text { - increasing production } \\
\text { for pain relief brands } \\
\text { such as Panadol and } \\
\text { multi-vitamins and } \\
\text { dietary supplements } \\
\text { such as Emergen-C and } \\
\text { Centrum }\end{array}$ & $\begin{array}{l}\text {-increasing the } \\
\text { production of the } \\
\text { most demanded } \\
\text { drugs } \\
\text { - expanded the } \\
\text { use of Digital } \\
\text { Operations } \\
\text { Center }\end{array}$ & $\begin{array}{l}\text {-implementing } \\
\text { general } \\
\text { international travel } \\
\text { restrictions }\end{array}$ \\
\hline
\end{tabular}

\section{Recommendations for stabilising pharmaceutical supply chains}

The consequences of Britain leaving the EU are already obvious. The supply chain is hampered at all levels. However, it is possible to say that pharmaceutical companies have taken timely and adequate measures to ensure guaranteed deliveries to all other EU countries, and not only. Undoubtedly, this leads to many additional costs for the companies linked to making changes to packaging; getting the necessary 
licenses; duplicating testing in the UK and EU and so on. If we put Brexit aside and take into account the pandemic, we will notice that pharmaceutical companies are reorienting their activities into the global economic leader - China. Amid challenges brought by Covid-19, China's pharmaceutical industrial chain remains competitive and resilient, playing an integral part in continuously bringing stability to the global healthcare ecosystem. The British pharma industry companies rely on their Chinese reserves to be maintained without a shortage of pharmaceuticals during this epidemic period. Even in a pandemic period, supply delays are almost non-existent due to preexisting supply chain facilities in China.

The management of pharmaceutical supply chains has become more complex because it involves the life-saving interest of human beings and requires the participation of different stakeholders such as pharmaceutical manufacturers, wholesalers, distributors, customers, information service providers and regulatory agencies. However, the pharmaceutical companies in UK could take additional measures to ensure the supply chain process: 1) could replenish raw material stocks, so that they can meet greater demand in the event of a crisis; 2) could return at least a part of the production of medicines back to Europe, for example in Germany; 3) could provide storage facilities in some countries in European Union in order to transport and cross the borders as faster as they can; 4) maintaining additional stocks; 5) planning the supply chain network design; 6) planning the delivery networks, online regulation of the supplies; 7) implementation of more air supplies in order to speed the transport of emergency medical products; 8) implementing additional "green lines" for trucks, transporting priority goods.

Undoubtedly, Covid-19 will lead to a reorganisation of medical supplies in Europe and particularly those from the UK. In times of crisis, there can always be a shortage of certain goods. In such a situation, the local economy needs to adapt quickly to those specific needs. This is why it is necessary to make a preliminary plan for action in an emergency situation. As regards Europe's dependence on China, it is possible to stimulate the production of medicines and pharmaceutical products in the UK through tax relief. It is necessary to ensure a sustainable pharmaceutical industrial ecosystem that stimulates Europe, including the UK. That would be the key driver for stimulating economic growth and workplaces.

\section{Conclusion}

We live in a time of deep crises that leave irreparable economic and social damages. As Katsarski (2019) mentions, Brexit is a symbol of the dominant tendency for disunity, conflict and insecurity. Brexit is the most visible, but certainly not the 
only sign of centrifugal tendencies in Europe over the last decade. Following the previous statements, the transformations in trade processes are inevitable. This became clear during the Brexit process, and even more clearly when the Covid-19 epidemic has occurred. Meanwhile the pharmaceutical industry is taking steps to balance retail chains so the supply of medicines reaches all EU countries. Undoubtedly, China is proving to be the force by which the effects of the pandemic leave an almost zero mark on their retail chains. Many pharmaceutical companies with a major presence in the UK, are looking to locate warehouses in China to ensure the supply of medicines and medical devices so they can be prepared in the event of subsequent adverse situations. In this way, the pharmaceutical business seeks certainty in the indefinite future. Leaving Britain and the lessons of the difficult process of separation have a sobering effect on the great expectations of civilisation and place a clearer emphasis on the balance between national interests and the idea of the future of European integration with its strategic coherence during the years with funding, growth and jobs, notable research and innovations (Boshnakov, 2013). Britain will try to position itself as a world-class financial centre, independent of the EU, but ensuring its interaction with China, India and the Union.

\section{References}

1. ABPI (2020). What impact will coronavirus have on the medicines supply chain? [online]. Available from: https://www.abpi.org.uk/medicine-discovery/covid-19/whatimpact-will-coronavirus-have-on-the-medicines-supply-chain/. [Accessed 6 Jun. 2020].

2. Boshnakov, P. (2006). Tsentralizatsiya ili detsentralizatsiya: sledva li obshtata regionalna politika na ES da zameni regionalnite politiki na stranitechlenki, Svetovno stopanstvo i globalizatsiya, chast 1, STENO, str. 197-205

3. Boshnakov, P. (2013). EU Cohesion policy after 2013. Proceedings of Jubilee International Scientific Conference dedicated to the $20^{\text {th }}$ anniversary of the establishment of International Economic relations department D.A. Tsenov Academy of EconomicsSvishtov "The future of integration, the future of the European Union", pp. 78-88.

4. Business Research Company (2018). The Growing Pharmaceuticals Market: Expert Forecasts and Analysis. [online]. Available from: https://blog.marketresearch.com/the-growing-pharmaceuticals-market-expertforecasts-and-analysis. [Accessed 6 Jun. 2020].

5. DeArment, A. (2019). Novartis stockpiles drugs amid Brexit supply chain concerns. MedCity News. [Online]. Available from: https://medcitynews. com/2019/01/novartis-stockpiles-drugs-amid-brexit-supply-chain-concerns/. [Accessed 6 Jun. 2020]. 
6. Marinov, G. et al. (2014). Evropeiska ikonomicheska integratziya, Trasnsportna politika na ES, Glava 16, ONGAL, str. 391-416

7. GlobalData (2020). COVID-19 EU border closures and Brexit impacts movement of medical supplies. GlobalData. [online]. Available from: https://globaldata.com/covid-19-eu-border-closures-and-brexit-impacts-movement-ofmedical-supplies/. [Accessed 30 May 2020].

8. GSK (2020). Our approach to Brexit. [online]. Available from: https://www.gsk.com/en-gb/media/resource-centre/our-approach-to-brexit/. [Accessed 30 May 2020].

9. IQVIA. (n.d.). Market share of top 10 pharmaceutical markets worldwide in 2018. Statista. [online]. Available from: https://www.statista.com/statistics/245473/ market-share-of-the-leading-10-global-pharmaceutical-markets/. [Accessed 6 Jun. 2020].

10. Katsarski, I. (2019). Brekzit - znamenie na epohata. In: B. Gradinarov, ed., Evropa i Brekzit: Kakvo e badeshteto na Evropeyskiya sayuz? $1^{\text {st }}$ ed. Sofia: BISFRIM. (In Bulgarian)

11. Leonard, M. (2020). AstraZeneca adjusts supply chain for no-deal Brexit. [online]. Supply Chain Dive. Available from: https://www.supplychaindive.com /news/AstraZeneca-supply-chain-adjustment-Brexit/548694/. [Accessed 6 Jun. 2020].

12. McGuinness, M. (2020). Brexit and COVID-19: An end to both in 2020? [online]. 13 May 2020. The Parliament Magazine. Available from: https://www.theparliamentmagazine.eu/articles/opinion/brexit-and-covid-19-endboth-2020. [Accessed: 4 Jun. 2020].

13. Mullin, R. (2020). COVID-19 is reshaping the pharmaceutical supply chain. [online]. Chemical \& Engineering News. Available from: https://cen.acs.org/business/outsourcing/COVID-19-reshaping-pharmaceuticalsupply/98/i16. [Accessed 4 Jun. 2020].

14. Novartis (2020). Coronavirus. [online]. Available from: https://www.novartis.com/coronavirus. [Accessed 21 May 2020].

15. Palmer, E. (2020). As Brexit costs mount, Pfizer estimates $\$ 100 M$ to adapt its supply chain. [online]. FiercePharma. Available from: https://www. fiercepharma.com/pharma/as-brexit-costs-mount-pfizer-estimates-100m-to-adapt-itssupply-chain. [Accessed 6 Jun. 2020].

16. Pfizer (2020). How Pfizer is Responding. [online]. Available from: https://www.pfizer.com/health/coronavirus/how-pfizer-is-responding. [Accessed 31 May 2020].

17. Rincon-Aznar, A. (2020). Global value chains after COVID-19 and BREXIT: Is it the end of the world as we know it? [online]. 21 April 2020. National 
Institute of Economic and Social Research. Available from: https://www. niesr.ac.uk/blog/global-value-chains-after-covid-19-and-brexit-it-end-world-weknow-it. [Accessed 21 May 2020].

18. Roscoe, S. (2020). COVID-19 and two key supply-chains "UK Trade Policy Observatory. [online]. Available from: https://blogs.sussex.ac.uk/uktpo/2020/03/24/covid-19-and-two-key-supply-chains/. [Accessed 24 Mar. 2020].

19. Taleb, N. (2007). The Black Swan: The Impact of the Highly Improbable. New York: Random House.

20. Ti (2020). Ti Covid-19 Monitor: Coronavirus and the Pharmaceutical Supply Chain | Ti. Transport Intelligence. [online]. Available from: https://www.tiinsight.com/whitepapers/ti-covid-19-monitor-coronavirus-and-the-pharmaceuticalsupply-chain/. [Accessed 4 Jun. 2020].

21. Tong, C. (2020). Foreign pharmaceutical firms up investments in China amid COVID-19. [online]. Available from: https://news.cgtn.com/news/2020-0423/Int-1-big-pharma-increases-investments-in-China-during-COVID-19PVLe4LfJug/index.html. [Accessed 6 Jun. 2020].

22. WTO (n.d.). International Trade and Market Access Data. [online]. Available from: https://www.wto.org/english/res_e/statis_e/statis_bis_e.htm. [Accessed 6 Jun. 2020].

23. WTO (2020). Trade in medical goods in the context of tackling Covid-19. [online]. Available from: https://www.wto.org/english/news_e/news20_e/rese 03apr20_e.pdf. [Accessed 5 Jun. 2020]. 